\title{
Velga LAUGALE
}

Liepājas Universitāte

\section{FRAZEOLOĢISMU APGUVE AUGSTĀKAJĀ IZGLİTİBĀ: LINGVOKULTUROLOGISKAIS ASPEKTS}

\begin{abstract}
Anotācija. Raksta mērksis ir pievērst valodu docētāju uzmanību bagātajam ikvienas valodas frazeoloǵismu klāstam, kas tradicionāli valodas un kultūras apguvē tiek izmantots minimāli. Vispārpienemts ir atzinums, ka tieši frazeoloǵija atspogulo tautas kultūras īpatnības, jo valodas lietotāja ir pati tauta. Pētījuma objekts ir autores apkopotā pieredze darbā ar frazeoloǵismiem vairākos studiju kursos: leksikoloǵijā, leksikostilistikā un praktiskajā latviešu valodā. Mūsdienās lingvistikai raksturīgs plašs izpētes spektrs. Svarīgu vietu tajā ienem lingvokulturoloǵiskā pieeja valodas vienību apguvē. Jautājums par valodas un kultūras savstarpējiem sakariem ir aktuāls šodienas sabiedrībā, kurā arvien aktuālāka klūst pasaules problēmu globalizācija. Līdz ar to rodas nepieciešamība ievērot gan dažādu tautu universālo, gan specifisko uzvedības raksturu. Tāpat tautu savstarpējos sakaros nepieciešams savlaicīgi apzināties situācijas, kurās var rasties liela iespējamība starpkultūru nesapratnei. Svarīgi ir noteikt kultūras vērtības, kuras ir komunikatīvās uzvedības pamatā. Augstākās izglīīības līmenī šīs prasmes ir jāapgūst studentiem, kas dažādu iemeslu dēl nokluvuši citā kultūrvidē. Augstākajā izglīīībā līdz 20. gs. 90. gadiem studenti vairāk tika rosināti uz valodas formu iegaumēšanu un vārdu nozīmju atklāšanu (visbiežāk - tulkojot), tikai 90. gadu beigās latviešu valodas kā svešvalodas apguvē tika uzsvērts valodas semantiskais un praktiskais aspekts. Lingvokulturoloǵiskās pieejas didaktiskā pamatvienība ir lingvokulturēma. Lingvokulturēma ir valodas un kultūras vienība, jo tajā apvienojas gan valodiskā nozīme, gan kultūrjēga, kas pastāv ārpus valodas sistēmas. Lingvokulturēma var būt gan leksiska, gan sintaktiska vienība: vārds, vārdu savienojums, teikums, teksts (Gavrilina, Vulāne, 2008:21). Lingvokulturoloǵiskā valodas analīze no izpētes viedokla lauj valodas vienības iedalīt trīs tipos: vārdi un izteicieni, kuri pilnībā sakrīt salīdzināmajās valodās; vārdi un izteicieni, kuri dalēji sakrīt salīdzināmajās valodās; vārdi un izteicieni, kuri nesakrīt salīdzināmajās valodās. Dažādi lingvokulturoloǵiskie aspekti kopš 2005. gada ir arī Eiropas Frazeoloǵijas biedrības realizēta projekta mērkis - noskaidrot nevis atškirīgo, bet gan kopīgo, t. i., konstatēt frazeoloǵijas dalu, kas ir kopīga Eiropas valodām. Līdzšinējie projekta rezultāti lauj secināt, ka vienādi vai līdzīgi frazeoloǵismi ir sastopami pat 50 dažādās valodās. Idiomas ar līdzīgu leksisko un semantisko struktūru ir sastopamas arī valodās, kuras nav ǵenētiski radniecīgas un teritoriāli atrodas tālu cita no citas. Tajā pašā laikā jāatzīmē, ka katrai tautai ir sava specifiska kultūras pasaules aina, jo katrai tautai ir savs kultūrvēsturiskais celš uz to. Katras valodas frazeoloǵismu kopums atspogulo tās kultūrvidi, domāšanu un vērtības. Frazeoloǵismi rosina saskatīt tekstā kulturoloǵisku informāciju, tādējādi studentiem tiek dota iespēja izkopt komunikatīvo, valodas, sociokultūras un mācību kompetenci. Šīs iespējas ir aktuālas, ja grupā mācās vairāku tautību studenti, kas dažādu iemeslu dēl nokJuvuši citā
\end{abstract}


kultūrvidē, jo viendabīgā kultūras vidē tās ir tikai formālas. Darbā ar frazeoloǵismiem rodas arī problēmas: atškirīgas frazeoloǵismu teorijas; studenti nezina frazeoloǵismus; zina, bet nelieto; nevar/ nedrīkst burtiski tulkot pārnestās nozīmes; dažādas asociācijas (piem., saule); dažāds konteksts arī vienam frazeoloǵismam (drosmìgs kā lauva, dusmīgs kā lauva); frazeoloǵismu ekspresivitāte jāapgūst īpaši. Lingvokulturēmu apguve rada jaunas iespējas: paplašināt vārdu krājumu apgūt savas valodas un kultūras mantojumu; apgūt citu kultūrvidi (katras tautas vērtības, stereotipi, uzvedības normas, runas etiketes formulas, paražas, dzīvesveids u. tml.); bagātināt savstarpējo sazinu, respektējot kultūras mantojumu; radīt interesi/motivāciju gan valodnieciskiem, gan ekstralingvistiskiem pētījumiem. Šāda informācija bagātina abas puses, jo, valodas lietotāji kultūru sastatījumā, daloties pieredzē, apgūst citu tautu kultūrtradīcijas.

Atslēgas vārdi: frazeoloǵismi, lingvokulturoloǵija, lingvokulturēma, kompetence.

\section{Ievads}

Mūsdienās lingvistikai raksturīgs plašs izpētes spektrs. Svarīgu vietu tajā ieñem lingvokulturoloǵiskā pieeja valodas vienību apguvē. Jautājums par valodas un kultūras savstarpējiem sakariem ir visnotal aktuāls šodienas sabiedrībā, kurā arvien aktuālāka klūst pasaules problēmu globalizācija. Līdz ar to rodas nepieciešamība ievērot gan dažādu tautu universālo, gan specifisko uzvedības raksturu. Tāpat tautu savstarpējos sakaros nepieciešams savlaicīgi apzināties situācijas, kurās var rasties liela iespējamība starpkultūru nesapratnei. Svarīgi ir noteikt kultūras vērtības, kuras ir komunikatīvās uzvedības pamatā.

Liepājas Universitātē starptautiskās studentu apmainas programmas ERASMUS ietvaros noslēgti divpusēji līgumi ar 47 Eiropas Savienības valstu augstskolām, dala viesstudentu arvien biežāk izvēlas kā obligāto vai izvēles kursu apgūt latviešu valodu. Šì studiju kursa docētāja ziñā ir dot studentiem iespēju valodas apguves kursā izkopt komunikatīvo, valodas, sociokultūras un mācību kompetenci. Šìs iespējas ir aktuālas, ja grupā mācās vairāku tautību studenti, kas dažādu iemeslu dēl nokluvuši citā kultūrvidē, jo viendabīgā kultūras vidē tās ir tikai formālas. Tāpat ar interesi tiek veikti nelieli pētījumi studiju programmās „Baltu filoloǵija un kultūra”, „Eiropas valodu un kultūru studijas” un „Ārējo sakaru vadība”.

Raksta mērksis ir pievērst valodu docētāju uzmanību ikvienas valodas frazeoloǵismu bagātajam klāstam, kas tradicionāli valodas un kultūras apguvē tiek izmantots minimāli. Pētījuma objekts ir autores apkopotā pieredze darbā ar frazeoloǵismiem vairākos studiju kursos: leksikoloǵijā, leksikostilistikā un praktiskajā latviešu valodā. Pētījuma ierosmes pamatā ir Liepājas Universitātes asociētās profesores Larisas Pavlovskas monogrāfija „Русская фразеология в зеркале латышского языка" (1998) un M. Gavrilinas un A. Vulānes didaktiskais materiāls "Valodā veldzējas tautas dvēsele" (2008) sociokultūras kompetences satura ìstenošanai Pamatizglītības standartā latviešu valodā (1.-9. klase), tajā aplūkots viens no būtiskiem valodas apguves aspektiem - iespēja apgūt latviešu valodu kā kultūras sastāvdalu. Teorētisko bāzi veido Latvijas valodniecības literatūrā paustās teorētiskās atzinas (A. Laua, E. Kokare), arī krievu valodnieku pētījumi 
un atzinumi lingvokulturoloǵijā (R. Frumkina, A. Hrolenko, V.Karasiks). Mūsdienu krievu valodniecībā ir virkne darbu, kas veltīti īpaši frazeoloǵismu analīzei lingvokulturoloǵiskā aspektā (piem., Брагина, 1999; Телия, 1998).

Augstākajā izglītībā līdz 20. gs. 90. gadiem studenti vairāk tika rosināti uz valodas formu iegaumēšanu un vārdu nozīmju atklāšanu (visbiežāk - tulkojot), tikai 90. gadu beigās latviešu valodas kā svešvalodas apguvē tika uzsvērts valodas semantiskais un praktiskais aspekts.

Jāpiebilst, ka lingvokulturoloǵija kā patstāvīgs virziens lingvistikā aizsākās tikai 20. gs. devindesmitajos gados, kad izveidojās un sāka strauji attīstīties jauna starpzinātnuu nozare, kuras centrā ir valoda un kultūra. 20. gs. beigās un 21. gs. sākumā vērojams lingvokulturoloǵijas uzplaukums. Pēdējos 10 gados gandrīz visās Eiropas valstīs ir notikušas lingvokulturoloǵijas konferences, pēc tām apkopoti un izdoti to materiāli un publikācijas. Nepieciešamību pēc šāda aspekta pētījumiem veicināja revolūcija valodniecībā, kura, kā raksturo valodniece R. Frumkina, "sākās tad, kad atklājās sava veida strupcelšs: izrādījās, ka zinātnē par cilvēku nav vietas galvenajam, kas radījis cilvēku un vina intelektu - kultūrai" (Фрумкина, 1996, p. 104).

Lai gan pats valodniecības virziens ir jauns, jāatzīmē, ka savos darbos idejas par to jau izteikuši ievērojamie krievu valodnieki V. Vinogradovs (В. В. Виноградов), ukrainu izcelsmes slāvu filologs A. Potebnna ( $A$. А. Потебня), arī citi. Arī latviešu valodniece Elza Kokare savā monogrāfijā "Latviešu un vācu sakāmvārdu paralēles" (1988) citējusi un tulkojusi vācu mācītāja Gotharda Frīdriha Stendera (1714-1796) izveidotās latviešu gramatikas (Lettissches Lexikon, 1789) priekšvārda norādi, ka tos „nepieciešams labi iepazīt, jo tie kopīgā sadzīvē bieži sastopami un loti labi atsedz latviešu ǵēniju un domāšanas veidu un jo sevišksi tajos valdošo lakonisko stilu, turklāt parasti tie ir ar sevišḱ nozīmīgu jēgu." (Kokare, 1988, p. 7). Pasaules uztvere, kas ietverta sakāmvārdos un frazeoloǵismos, atnes līdz mūsdienām priekšstatus, kas veidojušies pasaules kultūras apzināšanā katrai tautai.

Tādējādi idejas par kultūras un valodas apvienošanos ir auglīgas mūsdienu lingvistikā. Tās, ja nespēj radīt jaunas zināšanas, tad jaunu ievirzi dažos tradicionālos aspektos gan sniedz, tajā skaitā arī skolu un augstskolu sistēmā. Filologs Vladimirs Karasiks uzsver, ka humanitāro zinātņu attīstībā liela nozīme ir saistībai ar citām zinātnēm, kā psiholoǵiju, socioloǵiju, etnogrāfiju, kulturoloǵiju (Карасик, 2004, p. 390).

Tā kā lingvokulturoloǵija ir samērā jauna valodniecības nozare, ir virkne darbu, kuros tiek precizēta šīs zinātnes terminoloǵija un izstrādātas tās metodes. Pēc Aleksandra Hrolenko (Хроленко A. T.) domām, viens no galvenajiem virzieniem ir frazeoloǵismi, kur par analīzes objektiem klūst atseviški vārdi saistībā ar citiem vārdiem. Vārds ir pasaules konceptualizācijas fakts, tā sasniegumu rezultāts, garīgās, materiālās vai mākslas kultūras vārds. Autors uzskata, ka vārdu saistījums dalāms - pastāvīgajos un epizodiskajos. Pastāvīgais vārdu saistījums raksturo pasaulsredzējumu, bet epizodiskais - pasaulsredzējuma attīstības punktus (Хроленко, 2004, р. 72). 
Lingvokulturoloǵiskās pieejas didaktiskā pamatvienība ir lingvokulturēma. Lingvokulturēma ir valodas un kultūras vienība, jo tajā apvienojas gan valodiskā nozīme, gan kultūrjēga, kas pastāv ārpus valodas sistēmas. Lingvokulturēma var būt gan leksiska, gan sintaktiska vienība: vārds, vārdu savienojums, teikums, teksts (Gavrilina, Vulāne, 2008, p. 21).

Runājot par lingvokulturoloǵijas galveno problēmu, t. i., par starpkultūru nesakritību, valodnieks V. Karasiks nosaka šīs zinātnes uzdevumus. Tās izpētē ietilpst:

- priekšmeti un parādības, kas ir unikālas atsevišḱkai kultūrai,

- konkrētas tautas uzvedības specifika,

- mīti, leǵendas, teikas, sakāmvārdi un parunas, kā arī citas folkloras formas,

- bērnu skaitāmpantinii, vārdi no dziesmām un multiplikācijas filmām, ievērojamu cilvēku izteicieni utt.,

- nacionālie simboli (Карасик, 2004, p. 390).

Lingvokulturoloǵiskā valodas analīze no izpētes viedokla lauj valodas vienības iedalìt trīs tipos:

1) vārdi un izteicieni, kuri pilnībā sakrīt salīdzināmajās valodās;

2) vārdi un izteicieni, kuri dalēji sakrīt salīdzināmajās valodās;

3) vārdi un izteicieni, kuri nesakrīt salīdzināmajās valodās.

\section{Problēmas darbā ar frazeoloǵismiem}

Nevienmēr, konstatējot atškirības valodā, ir iespējams precīzi noteikt, vai konkrētā valodas vienība ir frazeoloǵisms. Tā kā dažādās valodās ir atškirīgas frazeoloǵismu teorijas un nav ìsti vienotas koncepcijas par to, kas ir frazeoloǵismi un „nefrazeoloǵismi”, šajā rakstā par frazeoloǵismiem tiek uzskatītas stabilas leksikas vienības, kuru nozīme ir runātājam labi zināma un kuras runājot tiek reproducētas, nevis konstruētas. Valodniece Velta Rūkse-Dravina uzsver, ka dzimtās valodas runātāji frazeoloǵismus lieto spontāni un automātiski, nedomājot par atsevišḱ vārdu nozīmi un nedarinot tos katru reizi no jauna (Rūke-Dravina, 1992, p. 147). Strīdīgs ir jautājums par frazeoloǵijas apjomu - vai sakāmvārdus un parunas ietilpināt frazeoloǵijā vai atstāt ārpus tās? E. Kokare uzsver, ka sakāmvārdi un parunas pa lielākai dalai ir frazeoloǵiski veidojumi (Kokare, 1980, p. 5).

Apkopojot studentu aptaujas rezultātus, var secināt, ka nereti studentu zināšanu pašvērtējums nesakrīt ar reālo, kaut gan vispārīgā (nojausmas) līmenī vini diezgan veiksmīgi tikuši galā ar frazeoloǵismu skaidrošanu. Tāpat praksē konstatēts, ka izpratne par frazeoloǵismu lietošanu un to vietu latviešu kultūrā ir nepilnīga, arī filoloǵijas studenti no 4000 "Latviešu frazeoloǵijas vārdnīcā" ievietotajiem frazeoloǵismiem (kopējais ekscerptu skaits kartotēkā ir aptuveni 120 000) zina nelielu dalu, bez tam lielākoties tie ir tikai pasīvajā leksikā (Laua, 2000, p. 5). Lai savu valodu veidotu krāsaināku, izteiksmīgāku, saturiski bagātāku jāzina arī frazeoloǵismi. 


\section{Lingvokulturoloǵiskie aspekti}

Studentiem interesants ir jautājums, kā vērtēt frazeoloǵiskās paralēles vairākās valodās. Profesors Andrejs Veisbergs uzskata, ka ir iespējama vienādu frazeoloǵismu veidošanās vairākās valodās neatkarīgi vienai no otras: „Teritoriālā tuvība, līdzīgie dabas un sadzīves apstākli, cilvēka uztveres un mentalitātes universālās iezīmes padara šādu iespējamību loti ticamu. Sevišksi tas attiecas uz vienkāršiem, neizvērstiem frazeoloǵismiem, somatiskām un komparatīvām vienībām" (Veisbergs, 1988, p. 139). Jaunākie pētījumi dalēji apstiprina A. Veisberga secinājumus.

Eiropas Frazeoloǵijas biedrība kopš 2005. gada realizē projektu, kurā ieklauts līdz šim nepieredzēti liels valodu skaits (to vidū ir arī latviešu valoda). Projekta mērksis ir noskaidrot nevis atškirīgo, bet gan kopīgo - konstatēt frazeoloǵijas dalu, kas ir kopīga Eiropas valodām. Līdzšinējie projekta rezultāti lauj secināt, ka vienādi vai līdzīgi frazeoloǵismi ir sastopami 30, 40 un pat vairāk nekā 50 dažādās valodās. Idiomas ar līdzīgu leksisko un semantisko struktūru ir sastopamas arī valodās, kuras nav ǵenētiski radniecīgas un teritoriāli atrodas tālu cita no citas. Projekta īstenotāji ir izdarījuši vairākus būtiskus secinājumus:

1) noteiktu idiomu esamība valodā nav atkarīga ne no valodā lietotā alfabēta (latīnu alfabēts vai kirilica), ne no reliǵijas, pie kuras pieder vairums valodas runātāju;

2) valodu ǵenētiskā radniecība nenozīmē, ka tajās noteikti ir vienādas idiomas;

3) pētījums neapstiprina pienēmumu par anglu valodas spēcīgo ietekmi uz Eiropas tautu frazeoloǵiju.

Lielai dalai Eiropas valodās izplatīto idiomu ir paralēles arī latviešu valodā. Daudzās valodās eksistējoši ekvivalenti frazeoloǵismi ir nevis aizguvumi, bet atšḱrīgās valodās notikušas savstarpēji neatkarīgas metaforizācijas rezultāts (Smiltena, 2008, p. 159-164).

Tajā pašā laikā jāatzīmē, ka katrai tautai ir sava specifiska kultūras pasaules aina, jo katrai tautai ir savs kultūrvēsturiskais celš uz to. Katras valodas frazeoloǵismu kopums atspogulo tās kultūrvidi, domāšanu un vērtības. Latviešu frazeoloǵismi tieši nosauc latviskajai kultūrvidei raksturīgus, savdabīgus jēdzienus. Piemēram, latviskie frazeoloǵismi izskrien kā vilks caur Rīgu, līst kā pa Jāniem, pazūd kā žĩds pa Mikelliem u. tml. "Latvietis smaida kā mēness, bet krievu cilvēks - kā nospodrināts patvāris. Neviens ar savu patvāri uz Tulu nebrauc, saka krievi, bet latvieši šo pašu spriedumu pauž teicienā Neviens audeklus uz Piebalgu neved," saka valodniece Sarma Klavina. Vina uzsver: „Nosaucot parādību vārdā, dažādas tautas var pievērst uzmanību atškirīgām tās pazīmēm, tādējādi var veidoties atškirīgi vārdu tēli, kas katrs savā veidā virza uztveri, izraisa citādas asociācijas un nosaka vārdiem citu poētisko izmantojumu" (Klavina, 1997). 
Nozīmes nacionālā specifika, salīdzinot divu tautu frazeoloǵismus, spilgti saskatāma salīdzinot, piem., latviešu frazeoloǵismu kost pirkstos - loti nožēlot izdarīto, būt izmisušam, dusmoties (Laua, 2000, p. 931) ar atbilstošo krievu valodas frazeoloǵismu ar šo pašu nozīmi, tikai tas skan - локти кусать (Павловская, 1998, p. 171). Neatbilsmes tulkojumā parasti rada interesi arī par ekstralingvistiskajiem apstākliem, kas ir frazeoloǵisma pamatā, sal. : стрелянный воробей - vecs buks, считать ворон - zvirbulus skaitit, белая ворона - baltais zvirbulis; котлету сделать - samalt miltos, знает кошка, чьё мясо съела - suns zina, ko ēdis.

Īpašu uzmanību prasa frazeoloǵismi, kuru pamatā ir pārnestās nozīmes. Neiespējami bez papildu zināšanām iztulkot krieviski latviešu frazeoloǵismu vīrs kā ozols, jo krievu valodā ar ozola cietību un stiprumu ir salīdzināts nevis augums, bet cilvēka galva un burtiskais tulkojums nozīmē 'mulkkis, stulbenis'. Arī kāda Liepājas studenta atbilde viesstudentam, kurš latviešu valodu tikai mācās - gaidi ar maisu - (ar nozīmi 'gaidīt veltīgi') lika vilties cerībā doties uz veikalu.

Retāk sastopami semantiskie okazionālismi, kad frazeoloǵismu lieto ar citu nozīmi, piemēram, frazeoloǵisms likt uz zoba lietots nevis ar parasto nozīmi 'ēst', bet ar nozīmi 'asi vērsties pret kādu' (Laua, 1992, p. 44-45).

Jaunas nozīmes vecie frazeoloǵismi iegūst arī mūsdienās. Piemēram, frazeoloǵisms zelta rokas ar nozīmi 'labs speciālists' no 2006. gada saistībā ar toreizējo Veselības ministru Āri Auderu tikai Latvijā tiek lietots ar nozīmi 'ñemt kukulus'.

Jaunas asociācijas un, iespējams, arī nozīmes veidojas ne tikai atseviškjiem vārdiem, bet arī frazeoloǵismiem. Mācoties frazeoloǵismus, var konstatēt, ka to tradicionālās nozīmes noveco, piem., „frazeoloǵismu justies kā mājās parasti lieto, ja kāds jūtas labi, nepiespiesti, omulīgi, ja viss ir zināms, ierasts (Laua, 2000, p. 637). Šì brǐža sociālajā situācijā, kad dala iedzīvotāju dzīvo loti grūtos apstāklos, kad daudzas ǵimenes ir nelabvēlīgas un kad vienīgā iespēja bērnam labi justies (t. i., labāk kā mājās) ir bērnudārzā vai skolā, šī frazeoloǵisma lietošana svētku uzrunā un solījums vecākiem, ka „darīsim visu, lai jūsu bērni var pie mums justies $\boldsymbol{k a ̄}$ mājās", rada pārdomas par to, vai frazeoloǵisms šajā situācijā izvēlēts pareizi" (Laugale, 2008, p. 44).

Asociāciju atšķirības var rasties arī klimatisku apstāklu ietekmē, piem., saule latviešu studentiem parasti asociējas ar kaut ko mīlu un siltu, par to liecina arī Latvijas pirmsskolas iestāžu nosaukumi, jo 19 no tiem simboliskais nosaukums ir "Saulīte". Studentes no Turcijas stāsta, ka saule ir karsta, visu kaltē, dedzina, tādēl nav mīla. Savukārt "Latviešu frazeoloǵijas vārdnīcā" konstatētie nozīmes skaidrojumi studentiem ir sveši, sal.: 1) loti dailšs, skaists; 2) novec. pavisam skaidrs, neapšaubāms; morāli tīrs (Laua, 2000, p. 822).

Dažāds konteksts iespējams arī vienam frazeoloǵismam, tādēl komunikācijas akta dalībnieku kopīga konteksta zināšanas var rasties pārpratumi, piem., ja kāds saka - tu šodien esi kā lauva. „Latviešu valodas frazeoloǵijas vārdnīcā” škirklja frazeoloǵismam konstatēti 3 atšǩirīgi nozīmes skaidrojumi, sal. kā lauva - 1) loti drosmīgi, ar lielu intensitāti, enerǵiju; 2) nikni, dusmīgi; 3) Joti stiprs (Laua, 2000, p. 595). 
Svarīgi ir ne tikai saprast, ko saka. Būtiski ir zināt, ko teikt, kad, kam, kādē un kuru no frazeoloǵismiem izvēlēties, sal.:

sarkana kā roze - parasti saka zied kā roze par jaunu, skaistu sievieti, par sārtiem vaigiem (Laua, 2000, p. 1080);

sarkans kā vēzis - saka, ja cilvēks (parasti vīrietis) ir ljoti nosarcis vai tā seja spēcīga (parasti negatīva) pārdzīvojuma dēl kluvusi loti sarkana, ja kādam no aukstuma vai karstuma ir sarkana āda (Laua, 2000, p. 1353);

sarkans kā biete - saka, ja kāds stipri nosarkst, ir loti nosarcis (Laua, 2000, p. 138);

sārts kā ābols - veselīgs, sārts, apaliem vaigiem (Laua, 2000, p. 12).

Frazeoloǵismu ekspresivitāte jāapgūst īpaši, dzimtās valodas lietotājiem tā parasti grūtības nesagādā. Uzskatāmi šis nozīmes papildkomponents ieraugāms frazeoloǵiskajās sinonīmu rindās un nosakāms, izmantojot frazeoloǵismu vārdnīcas, piem., nomirt - aizmigt mūžīgā miegā; aiziet vin̄ā saulē; nolikt savu galvu; nolikt karoti; lauzt kaklu; atstiept kājas.

\section{Lingvokulturēmu apguve nepšaubāmi rada jaunas iespējas valodu apguvē}

1. Būtiska ir iespēja paplašināt vārdu krājumu. Ja frazeoloǵismi (t.i. vārdi) tiek iepazīti reizē ar stāstu, tie labāk paliek atmin̄ā.

2. Dzimtās valodas lietotājiem šĩ ir iespēja apgūt savas valodas un kultūras mantojumu.

3. Apgūt citu kultūrvidi (katras tautas vērtības, stereotipi, uzvedības normas, runas etiketes formulas, paražas, dzīvesveids $u$. tml.)

4. Lingvokulturoloǵiska informācija savstarpējā saziñā, respektējot kultūras mantojumu, bagātina abas puses, jo, valodas lietotāji kultūru sastatījumā, daloties pieredzē, apgūst citu tautu kultūrtradīcijas.

5. Vispārpienemts ir atzinums, ka tieši frazeoloǵija atspogulo tautas kultūras īpatnības, jo valodas lietotāja ir pati tauta. Vēlme iepazīt labāk savu (vai citu) tautu var radīt interesi/motivāciju gan valodnieciskiem, gan ekstralingvistiskiem pētījumiem.

\section{Literatūra}

Gavrilina, M., Vulāne, A. (2008). Valodā veldzējas tautas dvēsele. Rīga: Mācību grāmata.

Klavina, S. Par valodas un kultūras attieksmēm jeb Valoda kā spogulis, loga rūtis un krūze. Interneta adrese: http://www.vvk.Iv/index.php?sadala=157\&id=366. Vietne apmeklēta 2011. gada 1. decembrī.

Kokare, E. (1988). Latviešu un vācu sakāmvārdu paralēles. Rīga: Zinātne.

Kokare, E. (1980). Latviešu un lietuviešu sakāmvārdu paralēles. Rīga: Zinātne.

Laua, A. (1992). Latviešu valodas frazeoloǵija. Rīga: Zvaigzne. 
Laua, A., Ezerina, A., Veinberga, S. (2000). Latviešu frazeoloǵijas vārdnīca. Rīga: Avots.

Laugale, V. (2008). Par vārda izvēli saziñā. Valodas prakse: vērojumi un ieteikumi, 3, 38-45. Rīga: LU Akadēmiskais apgāds.

Rūkse-Dravina, V. (1992). Frazeoloǵismi Kārla Ievina romānā "Putras Dauksis". Valodas jautājumi: rakstu krājums. Rīga: Avots.

Smiltena, M. (2008). Eiropas un pasaules tautu valodās izplatītu frazeoloǵismu paralēles latviešu frazeoloǵijā. Vārds un tā pētīšanas aspekti, 12 (1), 159167. Liepāja: LiePA.

Veisbergs, A. (1988). Vācu cilmes frazeoloǵija latviešu valodā. Iš Valodas aktualitātes 1988, 138-147. Rīga: Zinātne.

Брагина, Н. Г. (1999). „Фрагмент лингвокультурологического лексикона (базовые понятия)". Фразеология в контексте культуры. Москва: Языки русской культуры, 131-138.

Павловская, Л. Г. (1998). Русская фразеология в зеркале латышского языка. Лиепая: ЛПА.

Филипченко, М. П. (2009). Пословицы и поговорки народов мира. Москва: Сова.

Фрумкина, Р. М. (1996). Есть ли у современной лингвистики своя эпистемология? Москва: ГУ ВШЭ.

Хроленко, А. Т. (2004). Основы лингвокультурологии. Москва: Академический Проект.

Карасик, В.И. (2004). Языковой круг: личность, концепты, дискурс: монография. 2-е изд. Москва: Гнозис.

Телия, В. Н. (1996). Русская фразеология: семантическе, прагматическе и лингвокультурологические аспекты. Москва: КГУ.

\section{Velga LAUGALE \\ Liepājas University \\ ACQUIRING PHRASEOLOGY IN HIGHER EDUCATION: LINGUA-CULTURAL APPROACH}

Summary. The article aims at drawing the attention of language teachers to a huge number of phraseologisms which exist in every language and which are traditionally rarely used while teaching and learning languages and cultures. The fact that phraseology shows the features of folk culture is now widely accepted. The subject of the research is the experience of the author, namely, the investigation of phraseologisms related with lexicology, the stylistics of lexis and Latvian language for practical uses. These days a wide range of investigation is characteristic of linguistics. Lingvo-culturologic viewpoint to the learning of units of speech takes an important part in the investigations. The question of interaction between language and culture is nowadays relevant in our society, which experiences the growth of global problems, therefore, it is becoming essential to consider the versatility and particularity of behavior of different nations. Looking at relations between different nations, it is important to foresee potential cultural misunderstandings. It is also important to determine cultural values which form the basis for communicational behavior. In higher education institutions these skills are obligatory for students who, for various reasons, get into different cultural environments. Until 1990 students were encouraged to memorize word forms and to unpack 
the meaning of words (usually by means of translation) and only at the end of the 90's the semantic and practical aspects of speech were highlighted in the process of teaching Latvian as a foreign language. The main unit of lingvo-culturologic viewpoint is lingvocultureme. Lingvocultureme belongs both to language and culture, as it unites the meaning of language and culture which exists outside the boundaries of the language system. Lingvocultureme may be the unit of both lexis and syntax: a word, a phrase, a sentence, a text (Gavrilina, Vulane, 2008, pp. 21). According to lingvo-culturologic language research, linguistic analysis allows to divide units of language into three types: words and sayings which totally coincide in the languages compared; words and sayings which partially coincide in the languages compared; words and languages which do not coincide in the language compared. Since 2005 various aspects of lingvo-culturology have also been the subject of the project which is carried out by the European Society of Phraseology. The aim of the project is to discover the similarities rather than differences, i.e. to find the part of phraseology which is common for European languages. The results of the previous project show that identical or similar phraseologisms can be found in nearly 50 languages. Idioms with similar lexical and semantic structure can be found even in languages which are not genetically connected and whose areas of usage are distant from each other. It is important to note that each nation has its own cultural vision of the world and a cultural-historic way. In the phraseologisms of each language the culture, the way of thinking and values of each nation are conveyed. Phraseologisms in texts encourage students to search for culturologic information, through which students can develop their communicative, language, socio-cultural and learning competences. These opportunities are important in the cases when students who get into different cultural environment for various reasons and who have different nationalities study in one group (in homogeneous cultural environment these opportunities are formal). Various problems are possible while learning phraseologisms: different theories on phraseologisms; students do not know phraseologisms; students know phraseologisms, but do not use them; it is impossible to translate the figurative sense of some words literally; different associations (e.g. sun); the same phraseologisms are used in different contexts (e.g. as brave as a lion, as angry as a lion); students need to learn the expressiveness of phraseologisms. While learning lingvoculturemes new opportunities are created: to develop lexis; to get familiarized with the heritage of your own language and culture; to know more about different cultural environment (the values, stereotypes, norms of behavior, speech etiquette, customs, way of living, etc. of each nation); enrich intercommunion paying respect to cultural heritage; to motivate language users to take interest in linguistic and extralinguistic research. Such information will enrich both sides, as language users who share their experience learn from the cultural traditions of other nations.

Keywords: idioms, lingvo-culturology, lingvocultureme, competences.

\section{Velga LAUGALE}

Liepojos universitetas

\section{FRAZEOLOGIZMU ISISAVINIMAS AUKŠTOJOJE MOKYKLOJE: LINGVOKULTŪROLOGINIS ASPEKTAS}

Santrauka. Straipsnio tikslas - atkreipti kalbu dèstytoju dèmesi i kiekvienos kalbos frazeologizmu gausybę, kuri, mokantis kalbos ir kultūros, tradiciškai vartojama minimaliai. Dabar jau visuotinai pripažistama nuomonè, kad būtent frazeologija parodo liaudies kultūros ypatumus. Tyrimo objektas yra autorès sukaupta patirtis - frazeologizmu tyrinejjimai, susiję su leksikologija, leksikos stilistika ir praktine latviu kalba. Šiandien lingvistikai būdingas platus tyrimu spektras. Svarbią vietą užima lingvokultūrologijos požiūris i kalbos 
vienetu mokymąsi. Kalbos ir kultūros sąveikos klausimas šiandien aktualus visuomenèje, kurioje dideja pasaulio problemu globalizacija, todèl tampa būtina atsižvelgti i ivairiu tautu elgesio universalumą ir specifiką. Žvelgiant i tautu tarpusavio ryšius reikia suprasti, kokiose situacijose potencialiai gali atsirasti kultūrinis nesusipratimas. Svarbu nustatyti kultūrines vertybes, kuriomis pagristas komunikacinis elgesys. Aukštosiose mokyklose šie igūdžiai privalomi studentams, dèl ivairiu priežasčiu atsidūrusiems kitoje kultūrinèje aplinkoje. Iki XX a. 10 dešimtmečio studentai buvo labiau raginami isidèmèti žodžiu formas ir atskleisti žodžio reikšmę (dažniausiai - vertimu), ir tik dešimtmečio pabaigoje latviu kaip užsienio kalbos mokymo procese buvo pabrèžtas kalbos semantinis ir praktinis aspektas. Pagrindinis lingvokultūrologinio požiūrio vienetas - lingvokultūrema. Lingvokultūrema - ir kalbos, ir kultūros vienetas, nes ji sujungia kalbos reikšmę, ir kultūros prasmę, egzistuojančią už kalbos sistemos ribu. Lingvokultūrema gali būti ir leksinis, ir sintaksinis vienetas: žodis, žodžiu junginys, sakinys, tekstas (Gavrilina, Vulane, 2008, p. 21). Remiantis lingvokultūrologiniais kalbos tyrimais, lingvistinè analize leidžia suskirstyti kalbos vienetus i tris tipus: žodžius ir posakius, kurie lyginamose kalbose visiškai sutampa; žodžius ir posakius, kurie lyginamose kalbose sutampa tik iš dalies; žodžius ir pasakymus, kurie lyginamose kalbose nesutampa. tvairūs lingvokultūrologijos aspektai nuo 2005 m. yra ir Europos frazeologijos asociacijos vykdomo projekto tikslas - išaiškinti ne tai, kas skirtinga, o tai, kas bendra, t. y. nustatyti Europos kalboms bendra frazeologijos dali. Ankstesnio projekto rezultatai rodo, kad vienodu ar panašiu frazeologizmu randama iki 50 skirtingu kalbu. Idiomu, turinčiu panašią leksinę ir semantinę struktūrą, esama ir tose kalbose, kurios nèra genetiškai susijusios ir kuriu vartosenos teritorijos toli viena nuo kitos. Beje, reikia pažymèti, jog kiekviena tauta turi savo specifini kultūrini pasaulio vaizdą ir kultūrini istorini kelią. Kiekvienos kalbos frazeologizmu visuma perteikia tautos kultūra, mąstymą ir vertybes. Frazeologizmai skatina tekste ižvelgti kultūrologinę informacija, per tai studentai gali plètoti komunikacinę, kalbos, sociokultūrinę ir mokymo kompetencijas. Šios galimybès yra svarbios, kai vienoje grupejje mokosi keliu tautybiu studentai, dèl ¿vairiu priežasčiu patekę i kitą kultūrinę aplinką (vienarūšèje kultūrineje aplinkoje minètos galimybès yra tiesiog formalios). Mokantis frazeologizmu, kyla ir problemų: skirtingos frazeologizmu teorijos; studentai nežino frazeologizmu; žino, bet nevartoja; negalima pažodžiui versti žodžio perkeltinès reikšmės; skirtingos asociacijos (pvz., saulè); tas pats frazeologizmas vartojamas skirtingame kontekste (narsus kaip liūtas, piktas kaip liūtas); frazeologizmu išraiškingumo studentai turi mokytis specialiai. Mokantis lingvokultūremu, sukuriama nauju galimybių: praplèsti leksiką; susipažinti su savo kalbos ir kultūros paveldu; daugiau sužinoti apie kitą kultūrinę aplinką (kiekvienos tautos vertybes, stereotipus, elgesio normas, kalbejjimo etiketo taisykles, papročius, gyvenimo būdą ir kt.); praturtinti tarpusavio bendravima gerbiant kultūros paveldą; motyvuoti domètis kalbotyros ir ekstralingvistiniais tyrinejimais. Ši informacija praturtins abi puses, nes kalbos vartotojai, dalydamiesi patirtimi, mokosi iš kitu tautu kultūros tradiciju.

Pagrindinès sąvokos: idiomos, lingvokultūrologija, lingvokultūrema, kompetencijos. 